\title{
CCSにおける鋼材腐食について
}

\author{
巴 保義* \\ * 国際石油開発帝石株式会社

\section{Corrosion of Steels in CCS Processes} \\ Yasuyoshi Tomoe* \\ * INPEX Corporation
}

\begin{abstract}
The main cause of the global warming is considered to be the increase in $\mathrm{CO}_{2}$ emission due to the developed economic activity of mankind. Nowadays, strict reduction of $\mathrm{CO}_{2}$ emission to the atmosphere is required to keep the rise in temperature less than $2.0^{\circ} \mathrm{C}$ after the industrial revolution. One potential technology is CCS (Carbon dioxide Capture and Storage) consisting of four processes, (1) Separation and recovery of $\mathrm{CO}_{2}$ from raw gases, (2) Transportation of dense phase $\mathrm{CO}_{2}$ to an injection site, (3)Injection of super critical $\mathrm{CO}_{2}$ into deep subsurface reservoirs, and (4) Confirmation of the safe storage of the injected $\mathrm{CO}_{2}$. However, $\mathrm{CO}_{2}$ is an acid gas and it becomes highly corrosive when it exists with liquid water, contaminants, and the variation of temperature and pressure. The corrosive conditions of the four processes are technically reviewed in relation to the corrosion behavior of steels.
\end{abstract}

Key words : global warming, $\mathrm{CO}_{2}$, four processes of CCS, corrosion of steels

\section{1. 地球温暖化と CCS (Carbon Dioxide Capture and Storage)}

発電などで使用される化石燃料に由来する温室効果ガ スである二酸化炭素 $\left(\mathrm{CO}_{2}\right)$ が大気に排出され，その大気 中濃度の継続的増加が地球温暖化の主要原因として問題 視されている。その $\mathrm{CO}_{2}$ を大気中に排出せず，分離・回 収して地下に貯留する CCS が温暖化に対する現実的対 策の一つと考えられている。これを受け，日本を含む世 界各地で CCS プロセスの実証プロジェクト，及び害用 プロジェクトが開始されている.

気候変動枠組条約第 21 回締約国会議(COP21) が 2015 年末にフランスで開催され，2020 年以降の地球温暖化対 策の枠組みをまとめた「パリ協定」を採択して終了した ${ }^{1)}$.

この枠組みは, 産業革命以後の気温上昇を $2.0^{\circ} \mathrm{C}$ 未満 に抑えるとともに， $1.5^{\circ} \mathrm{C}$ 未満に収まるよう努力すること を目的としている。これまでの国際的なコンセンサスで ある $2.0^{\circ} \mathrm{C}$ 目標から一歩踏み込んだ $1.5^{\circ} \mathrm{C}$ 目標にも言及す ることで，各国の積極的な取り組みを喚起している。ま た, 上記目標の達成に向け, 出来るだけ早期に世界の $\mathrm{CO}_{2}$ 排出量の増加を止め, 今世紀後半には実質的にゼロ とすることを目指す。その実現のためにCCS 技術の活 用が想定されている.

\section{CCS における鋼材腐食について}

$\mathrm{CCS}$ では高圧の $\mathrm{CO}_{2}$ を扱うプロセスが多く，水分が 共存すると鋼材に対して腐食環境となる。一般的には, 次の四つのプロセスから成る.

\footnotetext{
* 个157-0061 東京都世田谷区北烏山 9-23-30 (9-23-30, Kitakarasuyama,
} Setagaya-Ku, Tokyo, 157-0061 Japan)
1) 燃焼排ガス，天然ガス，合成ガスなどからの $\mathrm{CO}_{2}$ 分 離・回収

2) 高圧 $\mathrm{CO}_{2}$ の輸送

3) 高圧 $\mathrm{CO}_{2}$ の深部塩水層や枯渇油・ガス層への圧入

4) 圧入された $\mathrm{CO}_{2}$ の貯留 (圧入された $\mathrm{CO}_{2}$ の安全貯留の 確認，枯渇油・ガス層の場合には廃坑井の炭素鋼ケー シングパイプとの接触)

1)では，酸性ガスである $\mathrm{CO}_{2}$ を有機アルカリ性水溶 液であるアルカノールアミン類の水溶液に吸収させ, 加 熱により放出させるプロセスが有力な方法の一つであ る.しかし，加熱により $\mathrm{CO}_{2}$ が溶液から放出される部分 で厳しい腐食環境となる。

なお，このプロセスはコストがかさむことから，CCS プロセス全体のコスト削減の主要検討対象となっている.

2)では，輸送管内の圧力変動により水が析出し，その 中に原料ガス及び処理プロセスにより夾雑する不純物が 溶解することにより，腐食環境が形成される。

3)では，圧入層の深度が深く高温の場合には，圧入停 止時に $\mathrm{CO}_{2}$ が溶解した塩分濃度の高い地層水が坑底部を 濡らすことにより，鋼材にとっては厳しい腐食環境とな る.

4)では，圧入層が枯渇した油・ガス層の場合には，圧 入された $\mathrm{CO}_{2}$ が地層内を拡散し, 廃坑井の炭素鋼ケーシ ングパイプと接触することとなる．3）の場合と同様に高 温・高塩分濃度の場合には厳しい腐食環境が形成される.

\section{CCS における鋼材腐食解説特集ついて}

CCS における鋼材腐食分科会は 2011 年から活動を始 め, 研究報告, 関連技術報告, 及びそれらに関する意見 交換が行われている. それらの活動の中間的報告として, 2014 年の第 62 回材料と環境討論会(米子市)において, 課題セッションを開催させていただいた。本解説特集の 
多くはその時の報告をべースとしたものである.

2. の 1），3），4）に関しては分科会委員からの研究報告 を，2）に関しては関連技術報告を以下に記す。また，現 在進行中の苫小牧地点における CCS 実証プロジェクトの 概要についてもアップデートして解説していただく.

\section{4. 高圧 $\mathrm{CO}_{2}$ の輸送過程における鋼材腐食}

高圧 $\mathrm{CO}_{2}$ の輸送では温度・圧力変化により 水分が液化 し，その中に種々の不純物が溶解，濃化することにより 腐食性が高まる。主な不純物は, $\mathrm{SOx}, \mathrm{NOx}, \mathrm{O}_{2}, \mathrm{CO}$, $\mathrm{H}_{2} \mathrm{~S}, \mathrm{H}_{2} \mathrm{O}$ などである. しかし, それらの許容濃度に関 するコンセンサスは得られていないのが現状である。こ れらに関し多くの論文が提出されているが，それらは各 不純物を単独に扱っており, 相乗作用については不明で ある。

National Energy Technology Laboratory（NETL) は 43 の論文をレビューすることにより不純物の許容濃度を示 しているが, 排ガス, エネルギー変換プロセス, あるい は $\mathrm{CO}_{2}$ 回収プロセスの相違により, それらの值は大きく 異なっている ${ }^{2)}$.

腐食性の評価法に関しても各研究機関が工夫した方法 で実施されている．例えば, 細い振とう／回転型オート クレーブの底に装着した(水の凝縮を想定) 円形のホイル を試験片とし, $10 \mathrm{MPa}$ とした初期 $\mathrm{CO}_{2}$ 圧を減じ, 不純 物としての水, $\mathrm{SO}_{2}, \mathrm{NO}_{2}$ の影響を調べている ${ }^{3)}$. その 結果室温において $0.9 \mathrm{~mm} / \mathrm{y}$ という高い腐食速度が得ら れている.

微量の $\mathrm{SO}_{2}, \mathrm{NO}_{2}, \mathrm{O}_{2}$, 及び $\mathrm{H}_{2} \mathrm{O}$ 存在環境に対する試 験では，硫酸や硝酸，さらに元素硫黄の生成により，八 ステロイ製のオートクレーブ内の水分が特殊な色を呈し
ていたとのことで，その腐食性の高さが推測される ${ }^{3)}$. なお，輸送される高濃度 $\mathrm{CO}_{2}$ の状態を「dense phase」 と表現されることがあるが, $\mathrm{CO}_{2}$ が超臨界か液体の状態 であることを意味する。この状態の $\mathrm{CO}_{2}$ の比重は液体の 水に近く, 粘性はガス状の $\mathrm{CO}_{2}$ にほぼ等しいため, 輸送 に適している。

また, $\mathrm{CO}_{2}$ 分離・回収プロセスで使用されるアミン溶 液の混入の影響についても調べられており, MEA(モ) エタノールアミン) 濃度の増加により炭素鋼の腐食への 影響が，抑制から促進，さらに抑制へと変化するという 興味ある知見が得られている ${ }^{4)}$. しかし，これまでに得 られている実験室のデータが実際の高圧 $\mathrm{CO}_{2}$ 輸送過程の 腐食とどのように対応するかは不明である。

今後のアプローチとして repeatability (同一機関内の再 現性)と reproducibility(異なる機関の間の再現性)の優れ た評価法を確立し，超臨界 $\mathrm{CO}_{2}$ の条件において， $\mathrm{O}_{2}$, $\mathrm{N}_{2}, \mathrm{SO}_{2}, \mathrm{NOx}, \mathrm{H}_{2} \mathrm{~S}$, エチレングリコール, アミン類, 及びアンモニアなどの不純物の影響の評価が不可欠との 提言がなされている.

\section{参 考 文 献}

1) United Nations Framework Convention on Climate Change "Adoption of the Paris Agreement" (2015).

2) A. Dugstud, M. Halseid and B. Morland, Proc. EUROCORR 2014, Pisa, EFC, Paper No.O-7744 (2014).

3) A. Dugstud, M. Halseid, B. Morland and A. O. Sivertsen, Proc. CORROSION/2013, Houston, NACE, Paper No.2785 (2013).

4) A. Dugstud, M. Halseid and B. Morland, Proc. EUROCORR 2014, Pisa, EFC, Paper No.O-7743 (2014).

5) S. Papavinasam et al., Proc. CORROSION/2012, Houston, NACE, Paper No.C2012 (2012).

(2016年1月21日受理)

\section{要旨}

人類の経済活動の活発化により大気中に放出される $\mathrm{CO}_{2}$ 量の増大が, 産業革命以降の地球温暖化の原因 と考えられている。 2015 年末に開催された COP21 では, 従来の国際的コンセンサスである気温上昇を 2.0 ${ }^{\circ} \mathrm{C}$ 未満に抑えるとともに，1.5ㅇ未満に収まるよう努力することを加え，各国の積極的な取組を喚起してい る。そして，その実現のために CCS(Carbon dioxide Capture and Storage)技術の活用が想定されている. $\mathrm{CCS}$ は(1)原料ガスからの $\mathrm{CO}_{2}$ 分離・回収, (2)高圧 $\mathrm{CO}_{2}$ の輸送, (3)超臨界 $\mathrm{CO}_{2}$ の深部貯留層への圧入, (4) 圧入された $\mathrm{CO}_{2}$ の安全貯留の確認の 4 プロセスから成る。しかし, $\mathrm{CO}_{2}$ は酸性ガスであり, 水の存在と $\mathrm{CO}_{2}$ の不純物, 温度・圧力などの変化により, 装置材料に予期せぬ腐食損傷がもたらされる危険が 存在する。本報では, $\operatorname{CCS}$ の 4 プロセスと鋼材の腐食問題について概説する.

キーワード＼cjkstart地球温暖化, $\mathrm{CO}_{2}, \mathrm{CCS}$ の 4 プロセス, 鋼材腐食 